\title{
A Study on Standard of Living Kalamkari Artisans
}

\section{OPEN ACCESS}

Volume: 7

Issue: 2

Month: October

Year: 2019

P-ISSN: 2321-4643

E-ISSN: 2581-9402

Received: 7.9 .2019

Accepted: 26.9.2019

Published: 03.10.2019

Citation:

Ramya Sri, G. “A Study on Standard of Living

Kalamkari Artisans.” Shanlax

International Journal of

Management, vol. 7, no. 2,

2019, pp. 89-95.

\section{DOI:}

https://doi.org/10.34293/

management.v7i2.722

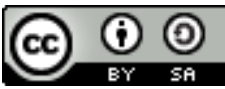

This work is licensed under a Creative Commons Attribution-ShareAlike 4.0 International License.

\author{
G.Ramya Sri \\ Assistant Professor, Badruka College of Commerce and Arts, Hyderabad, Telangana, India
}

Abstract

The birth place of textiles, India has always been known for its art, crafts, tradition and culture. The soothing weaves, vibrant colours, intricate embroideries, decorative motifs, and elaborate costumes have been most sought after inspirations and possessions. The integration of tradition with methods and techniques denotes the fact that work is treated as worship, and thus has been followed with great devotion and reverence.

Keeping in tune to its cultural traditions is one such textile craft, kalamkari, the hand painted and block printed textile of India. Hand painted and block printed kalamkari also known as the Machilipatnam kalamkari is widely used in clothing, home decor and lifestyle products today.

The objective of this research is to understand the evolution of hand painted and block printed kalamkari and the artisans, their life style, their standard of living. Secondary data was largely collected through books and also from blogs, newspapers, articles and various websites. To understand the standard of living of the artisans, a visit was paid to Machilipatnam. The research was exploratory and the findings were mainly qualitative in nature. After collecting the sufficient information, the paper analyses issues and challenges faced by the kalamkari artisans and then introduces possible solutions. Some conclusions are developed on the basis of this analysis.

Keywords: Artisans, Block Prints, Consumer's Perception, Hand Painted, Kalamkari.

\section{Introduction}

Kalamkari can be explained as Kalam - pen \&kari - work, i.e., art work done using a pen. Vegetable dyes which are absolutely natural are used to colour the designs applied on cloth. The art of painting using organic dyes on cloth was popular in several states of India, but this style of Kalamkari flourished at Kalahasti and at Masulipatnam. The Kalamkari tradition chiefly consists of scenes from Hindu mythology and epics. Figures of deities with rich borders were created for the temples. In Masulipatnam, the weavers were mostly involved in the block printing art, while at Kalahasti, the Balojas took to this art involving painting with kalam. Owing to Muslim rule in Golconda, the Masulipatnam Kalamkari was influenced by Persian designs, widely adapted to suit their taste.

\section{Literature Review}

Pooja Purohit (2013): In the research project titled "The study was on the traditional hand painted kalamkari to design a set of new age prints". Explored to bring innovation in Kalamkari prints and bring awareness about them amongst youngsters.

National Centre for Design and Product Development (2016): In the report titled "A report on design and technical development workshop on kalamkari at srikalahasti,tirupati", it was concluded that, the design and technical development workshop in kalamkari at Srikalahasti was a good opportunity to develop more new designs. 
Seshu Kumar Jujjuvarapu and A.Udaya Shankar (2016) In the research project titled "a study on purchase preference of women towards kalamkari products in ecommerce websites in A.P" it was concluded Colours, Designs, Quality, touch, feel, comfort, fit, price etc. of the kalamkari fabric have the great impact on consumer buying preference.

\section{Research Gap}

The review of literature revealed that many studies have been made on specific aspects of Kalamkari art such as, The study was on the traditional hand painted kalamkari to design a set of new age prints, The study was on kalamkari- the painted temple cloths, A report on design and technical development workshop on kalamkari at Srikalahasti, Change of the Technic of Kalamkari under Handcrafts Promotion Policy- Case Study of Temple Cloth in South India, a study on purchase preference of women towards kalamkari products in ecommerce websites in A.P, there is no study that has been made on the standards of living of the artisans, issues and challenges faced by them. So, a comprehensive study covering the standard of living of the artisans is needed.

\section{Need and Significance of the Study}

To bring out the life style of the artisans, The issues and challenges faced by them is needed as the art and artisans are becoming extinct.

\section{Objectives of the Study}

The main objective of the research is to study about the kalamkari artisans, their life style, standard of living, issues and challenges faced by the artisans.

\section{Sub Objectives}

- To understand the evolution of Kalamkari prints from history to present times.

- To study the Process of Kalamkari.

- To understand the areas in which kalamkari is used.

- To know the market trends in prints.

- To explore the possibilities in Kalamkari.

- To know the various promotion and development policies encouraged by the government.

\section{Hypothesis of the Study}

Based on the problems identified and the objectives set, the following hypotheses were formulated:

\section{Chisquare 1: Association of Number of Members in the Family and Monthly Income}

Null hypothesis: There is no association between the number of members in the family and the monthly income of the artisans.

Alternate hypothesis: There is an association between the number of members in the family and the monthly income of the artisans

\section{Chisquare 2: Association of Number of Members in the Family and Number of Earning Persons in the Family}

Null hypothesis: There is no association between the number of members in the family and number of earning persons in the family of the artisans.

Alternate hypothesis: There is an association between the number of members in the family and number of earning persons in the family of the artisans.

\section{Chisquare 3: Association of Monthly Income and Sufficiency of Monthly Income}

Null hypothesis: There is no association between the monthly income and sufficiency of the monthly income of the artisans.

Alternate hypothesis: There is an association between the monthly income and sufficiency of the monthly income of the artisans.

Chisquare 4: Association of Number of Members in the Family and Sufficiency of Monthly Income Null hypothesis: There is no association between the number of members in the family and sufficiency of monthly income of the artisans.

Alternate hypothesis: There is an association between the number of members in the family and sufficiency of monthly income of the artisans.

Chisquare 5: Association of Financial Problems and Health Problems

Null hypothesis: There is no association between the financial problems and the health problems of the artisans.

Alternate hypothesis: There is an association between the financial problems and the health 
problems of the artisans.

Chisquare 6: Association of Monthly Income and Health Problems

Null hypothesis: There is no association between the monthly income and the health problems of the artisans.

Alternate hypothesis: There is an association between the monthly income and the health problems of the artisans.

Chisquare 7: Association of Monthly Income And Sufficiency of Income for Children's Education

Null hypothesis: There is no association between the monthly income and the sufficiency of income for their children's education of the artisans.

Alternate hypothesis: There is an association between the monthly income and the sufficiency of income for their children's education of the artisans.

\section{Research Methodology}

The type of the project is analytical and survey.
The study on Kalamkari artisans was confined to the region called Pedana in Machilipatnam. Convenience Sample is used. A sample size of 100 is chosen to study about the artisans. Percentage method, ANOVA and Chi-Square tests are used with the help of SPSS Software for data analysis. Since the standard of living matter is a sensitive one, the artisans were not ready to disclose information so openly in front of their owners. Only limited samples could be made due to the time constraint hence the facts may not be generalized.

\section{Data Analysis}

Chisquare 1: Association of Number of Members in the Family and Monthly Income

Null hypothesis: There is no association between the number of members in the family and the monthly income of the artisans.

Alternate hypothesis: There is an association between the number of members in the family and the monthly income of the artisans.

\begin{tabular}{|l|c|c|c|c|c|}
\hline \multirow{2}{*}{$\begin{array}{c}\text { Number of members } \\
\text { in the family }\end{array}$} & \multirow{2}{*}{ Frequencies } & \multicolumn{3}{|c|}{ Monthly Income } & \multirow{2}{*}{ Total } \\
\cline { 3 - 6 } & $\begin{array}{c}\text { below 10,000 } \\
\text { Rs. }\end{array}$ & $\begin{array}{c}\mathbf{1 0 , 0 0 0 - 3 0 0 0 0} \\
\text { Rs. }\end{array}$ & $\begin{array}{c}\mathbf{3 0 , 0 0 0 - 5 0 , 0 0 0} \\
\text { Rs. }\end{array}$ & \\
\hline \multirow{2}{*}{$2-4$ members } & Observed & 6 & 37 & 15 & 58 \\
\cline { 2 - 6 } & Expected & 8.7 & 31.9 & 17.4 & 58.0 \\
\hline \multirow{2}{*}{$5-7$ members } & Observed & 8 & 18 & 13 & 39 \\
\cline { 2 - 6 } & Expected & 5.9 & 21.5 & 11.7 & 39.0 \\
\hline \multirow{2}{*}{$8-10$ members } & Observed & 0 & 0 & 2 & 2 \\
\cline { 2 - 6 } & Expected & .3 & 1.1 & .6 & 2.0 \\
\hline \multirow{2}{*}{$11-13$ members } & Observed & 1 & 0 & 0 & 1 \\
\cline { 2 - 6 } & Expected & .2 & .6 & 3 & 1.0 \\
\hline \multirow{2}{*}{ Total } & Observed & 15 & 55 & 30.0 & 100 \\
\cline { 2 - 6 } & Expected & 15.0 & 55.0 & & 100.0 \\
\hline
\end{tabular}

Chi-Square Test

\begin{tabular}{|c|c|c|c|}
\hline & value & df & Sig. \\
\hline Pearson chi-square & 13.807 & 6 & .032 \\
\hline
\end{tabular}

\section{Decision}

Since "p" value i.e., 0.032 is less than 0.05 at 6 degrees of freedom, Reject null hypothesis and accept the alternate hypothesis. Hence there is an association between the number of members in the family and the monthly income of the artisans.
Chisquare 2: Association of Number of Members in the Family and Number of Earning Persons in the Family

Null hypothesis: There is no association between the number of members in the family and number of earning persons in the family of the artisans. 
International Journal of Management

Alternate hypothesis: There is an association number of earning persons in the family of the between the number of members in the family and artisans.

\begin{tabular}{|l|c|c|c|c|c|c|}
\hline \multirow{2}{*}{$\begin{array}{c}\text { Number of members in } \\
\text { the family }\end{array}$} & \multirow{2}{*}{ Frequencies } & \multicolumn{4}{|c|}{ No of Earning persons in the family } & \multirow{2}{*}{ Total } \\
\cline { 3 - 8 } & & one person & 2 people & 3 people & 4 people & \\
\hline \multirow{2}{*}{$2-4$ members } & Observed & 23 & 35 & 0 & 0 & 58 \\
\cline { 2 - 8 } & Expected & 19.7 & 33.1 & 4.6 & .6 & 58.0 \\
\hline \multirow{2}{*}{$5-7$ members } & Observed & 9 & 21 & 8 & 1 & 39 \\
\cline { 2 - 8 } & Expected & 13.3 & 22.2 & 3.1 & .4 & 39.0 \\
\hline \multirow{2}{*}{$8-10$ members } & Observed & 2 & 0 & 0 & 0 & 2 \\
\cline { 2 - 8 } & Expected & .7 & 1.1 & .2 & .0 & 2.0 \\
\hline \multirow{2}{*}{$11-13$ members } & Observed & 0 & 1 & 0 & 0 & 1 \\
\cline { 2 - 8 } & Expected & .3 & .6 & .1 & .0 & 1.0 \\
\hline \multirow{2}{*}{ Total } & Observed & 34 & 57 & 8 & 1 & 100 \\
\cline { 2 - 7 } & Expected & 34.0 & 57.0 & 8.0 & 1.0 & 100.0 \\
\hline
\end{tabular}

\section{Chi-Square Test}

\begin{tabular}{|c|c|c|c|}
\hline & Value & df & Sig. \\
\hline Pearson Chi-Square & 20.540 & 9 & .015 \\
\hline
\end{tabular}

\section{Decision}

Since "p" value i.e., 0.015 is less than 0.05 at 9 degrees of freedom, Reject null hypothesis and accept the alternate hypothesis. Hence there is an association between the number of members in the family and number of earning persons in the family of the artisans.

\section{Chisquare 3: Association of Monthly Income and} Sufficiency of Monthly Income

Null hypothesis: There is no association between the monthly income and sufficiency of the monthly income of the artisans.

Alternate hypothesis: There is an association between the monthly income and sufficiency of the monthly income of the artisans.

\begin{tabular}{|c|c|c|c|}
\hline \multirow{2}{*}{ Monthly income } & \multicolumn{2}{|c|}{ Sufficiency of Income } & \multirow{2}{*}{ Total } \\
\cline { 2 - 3 } & Yes & No & \\
\hline below 10,000 Rs. & 2 & 13 & 15 \\
\hline 10,000-30000 Rs. & 10 & 45 & 55 \\
\hline 30,000-50,000 Rs. & 5 & 25 & 30 \\
\hline Total & 17 & 83 & 100 \\
\hline
\end{tabular}

Chi-Square Test

\begin{tabular}{|l|l|l|l|}
\hline & Value & df & Sig. \\
\hline Pearson Chi-Square & .200 & 2 & .905 \\
\hline
\end{tabular}

\section{Decision}

Since "p" value i.e., 0.905 is greater than 0.05 at 2 degrees of freedom, Accept null hypothesis. Hence there is no association between the monthly income and sufficiency of the monthly income of the artisans.

\section{Chisquare 4: Association of Number of Members} in the Family and Sufficiency of Monthly Income

Null hypothesis: There is no association between the number of members in the family and sufficiency of monthly income of the artisans.

Alternate hypothesis: There is an association between the number of members in the family and sufficiency of monthly income of the artisans.

\begin{tabular}{|l|c|c|c|}
\hline \multirow{2}{*}{$\begin{array}{c}\text { Number of } \\
\text { members }\end{array}$} & \multicolumn{2}{|c|}{ Sufficiency of Income } & \multirow{2}{*}{ Total } \\
\cline { 2 - 3 } & Yes & No & \\
\hline 2-4 members & 12 & 46 & 58 \\
\hline $5-7$ members & 4 & 35 & 39 \\
\hline $8-10$ members & 0 & 2 & 2 \\
\hline $11-13$ members & 1 & 0 & 1 \\
\hline \multicolumn{1}{|c|}{ Total } & 17 & 83 & 100 \\
\hline
\end{tabular}

\begin{tabular}{|} 
Chi-Square Test \\
\begin{tabular}{|c|c|c|c|}
\hline & Value & df & Sig. \\
\hline Pearson Chi-Square & 7.109 & 3 & .069 \\
\hline
\end{tabular}
\end{tabular}




\section{Decision}

Since "p" value i.e., 0.069 is greater than 0.05 at 3 degrees of freedom, Accept null hypothesis. Hence there is no association between the number of members in the family and sufficiency of monthly income of the artisans.

\section{Chisquare 5: Association of Financial Problems and Health Problems}

Null hypothesis: There is no association between the financial problems and the health problems of the artisans.

Alternate hypothesis: There is an association between the financial problems and the health problems of the artisans.

\begin{tabular}{|c|c|c|c|}
\hline \multirow{2}{*}{$\begin{array}{c}\text { Financial } \\
\text { problems }\end{array}$} & \multicolumn{2}{|c|}{ Health Problems } & \multirow{2}{*}{ Total } \\
\cline { 2 - 3 } & Yes & No & \\
\hline Yes & 55 & 42 & 97 \\
\hline No & 0 & 3 & 3 \\
\hline Total & 55 & 45 & 100 \\
\hline
\end{tabular}

Chi-Square Test

\begin{tabular}{|c|c|c|c|}
\hline & Value & df & Sig. \\
\hline Pearson Chi-Square & 3.780 & 1 & .052 \\
\hline
\end{tabular}

\section{Decision}

Since "p" value i.e., 0.052 is greater than 0.05 at 1 degrees of freedom, Accept null hypothesis. Hence there is no association between the financial problems and the health problems of the artisans.

\section{Chisquare 6: Association of Monthly Income and Health Problems}

Null hypothesis: There is no association between the monthly income and the health problems of the artisans.

Alternate hypothesis: There is an association between the monthly income and the health problems of the artisans.

\begin{tabular}{|l|c|c|c|c|}
\hline \multirow{2}{*}{$\begin{array}{c}\text { Monthly } \\
\text { Income }\end{array}$} & \multirow{2}{*}{ Frequencies } & \multicolumn{2}{|c|}{ Health Problems } & \multirow{2}{*}{ Total } \\
\cline { 3 - 4 } & & Yes & No & \\
\hline below & Observed & 4 & 11 & 15 \\
\cline { 2 - 4 } 10,000 Rs. & Expected & 8.3 & 6.8 & 15.0 \\
\hline $\begin{array}{l}10,000- \\
30000 \text { Rs. }\end{array}$ & Observed & 31 & 24 & 55 \\
\cline { 2 - 4 } & Expected & 30.3 & 24.8 & 55.0 \\
\hline
\end{tabular}

\begin{tabular}{|c|c|c|c|c|}
\hline $30,000-$ & Observed & 20 & 10 & 30 \\
\cline { 2 - 5 } 50,000 Rs. & Expected & 16.5 & 13.5 & 30.0 \\
\hline \multirow{2}{*}{ Total } & Observed & 55 & 45 & 100 \\
\cline { 2 - 5 } & Expected & 55.0 & 45.0 & 100.0 \\
\hline
\end{tabular}

Chi-Square Test

\begin{tabular}{|c|c|c|c|}
\hline & Value & df & Sig. \\
\hline Pearson Chi-Square & 6.556 & 2 & .038 \\
\hline
\end{tabular}

\section{Decision}

Since "p" value i.e., 0.038 is less than 0.05 at 2 degrees of freedom, Reject null hypothesis and accept the alternate hypothesis. Hence there is an association between the monthly income and the health problems of the artisans.

\section{Chisquare 7: Association of Monthly Income and Sufficiency of Income For Children's Education}

Null hypothesis: There is no association between the monthly income and the sufficiency of income for their children's education of the artisans.

Alternate hypothesis: There is an association between the monthly income and the sufficiency of income for their children's education of the artisans.

\begin{tabular}{|c|c|c|c|c|}
\hline \multirow{2}{*}{$\begin{array}{l}\text { Monthly } \\
\text { Income }\end{array}$} & \multirow[t]{2}{*}{ Frequencies } & \multicolumn{2}{|c|}{$\begin{array}{c}\text { Sufficiency of Income } \\
\text { for Education }\end{array}$} & \multirow[t]{2}{*}{ Total } \\
\hline & & Yes & No & \\
\hline \multirow{2}{*}{$\begin{array}{l}\text { Below } \\
10,000 \text { Rs. }\end{array}$} & Observed & 3 & 12 & 15 \\
\hline & Expected & 8.6 & 6.5 & 15.0 \\
\hline \multirow{2}{*}{$\begin{array}{l}10,000- \\
30000 \text { Rs. }\end{array}$} & Observed & 35 & 20 & 55 \\
\hline & Expected & 31.4 & 23.7 & 55.0 \\
\hline \multirow{2}{*}{$\begin{array}{l}30,000- \\
50,000 \text { Rs. }\end{array}$} & Observed & 19 & 11 & 30 \\
\hline & Expected & 17.1 & 12.9 & 30.0 \\
\hline \multirow{2}{*}{ Total } & Observed & 57 & 43 & 100 \\
\hline & Expected & 57.0 & 43.0 & 100.0 \\
\hline
\end{tabular}

Chi-Square Test

\begin{tabular}{|c|c|c|c|}
\hline & Value & df & Sig. \\
\hline Pearson Chi-Square & 9.857 & 2 & .007 \\
\hline
\end{tabular}

\section{Decision}

Since "p" value 0.007 is less than 0.05 at 2 degrees of freedom, Reject null hypothesis and accept the alternate hypothesis. Hence there is an association between the monthly income and the sufficiency of income for their children's education of the artisans. 


\begin{tabular}{|l|c|c|c|}
\hline \multicolumn{4}{|c|}{ Table 1 Existing Facilities in House of the Respondents } \\
\cline { 2 - 3 } Existing facilities in the house & \multicolumn{2}{|c|}{ Responses } & \multirow{2}{*}{ Percent of Cases } \\
\cline { 2 - 3 } & Frequency & Percent & \\
\hline Electricity & 100 & $22.0 \%$ & $100.0 \%$ \\
\hline Toilet Facility & 100 & $22.0 \%$ & $100.0 \%$ \\
\hline Drinking water facility & 100 & $22.0 \%$ & $100.0 \%$ \\
\hline TV & 98 & $21.6 \%$ & $98.0 \%$ \\
\hline Refrigerator & 52 & $11.5 \%$ & $52.0 \%$ \\
\hline Washing Machine & 4 & $0.9 \%$ & $4.0 \%$ \\
\hline Total & 454 & $100.0 \%$ & $454.0 \%$ \\
\hline Sour
\end{tabular}

Source: Primary data

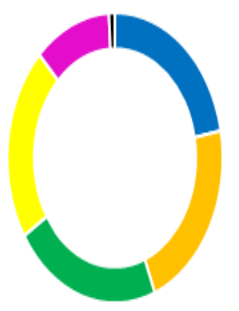

- Electricity

Toilet Facility

- Drinking water facility

TV

- Refrigerator

- Washing Machine

\section{Interpretation}

- It is found that about $100 \%$ of the respondents have electricity, toilet facility \& drinking water facility in their home.

- $0.9 \%$ of the respondents have washing machine in their home.

\section{Findings}

1. It is found that more women are giving employment in this field of kalamkari art.

2. It is found that most of the family members of the artisans are earning either being an artist or employed somewhere to earn their livelihood.

3. Most of the artisans had opted money lenders as the source of credit. More awareness has to be brought to the artisans about the banks.

4. All the artisans have electricity, toilet facility, and drinking water facility, in their homes. But when it came to TV only $98 \%$ of the artisans possess it. Refrigerator is possessed by $52 \%$ of the respondents. And just 4\% of the respondents possess washing machine. This means that still $\mathrm{TV}$, Refrigerator and washing machines are still considered as luxurious goods and possessed by only few artisans.
5. The help extended by the government was in the form of developing the skills of the artisans. Most of the manufacturers said that the government didn't extend any help in the form of subsidies for raw material, waiving of personal loan or business loan. The only help that was extended was to conduct a workshop to fine tune the artisans.

6. $100 \%$ of the artisans said that the working conditions are good which indicates that it is safe for even women to work in the manufacturing of kalamkari fabric.

7. The monthly income varies to one and other due to the nature and severity of the work they do. Usually women are paid less than men as women are mostly involved in the painting and the printed part. Whereas the men are given hard jobs. But the average monthly income the artisans receive is between Rs.10,000-30,000.

8. Most of the artisans claimed that the income they earn is not sufficient to run the family.

9. Since the income the artisans are earning is not sufficient, since they are indebted, many of them have financial problems.

\section{Conclusion}

It is concluded that women are given employment in this field of kalamkari art. Most of the family members of the artisans are earning either being an artist or employed somewhere to earn their livelihood. Most of the artisans do household savings but still indebted due to wants towards modernization. Money lenders are preferred to get credit. Refrigerator and washing machines, apart from the basic goods, are 
still considered as luxurious goods and possessed by only few artisans. The industry is deploying more and more artists due to the increased demand for the kalamkari fabric. The nature of the payment that the artisans receive is on daily basis for an 8 hours work. The monthly income varies to one and other due to the nature and severity of the work they do. Usually women are paid less than men as women are mostly involved in the painting and the printed part. Whereasthe men are given hard jobs. Most of the artisans claimed that the income they earn is not sufficient to run the family and many of them have financial problems. The help extended by the government was in the form of developing the skills of the artisans. The income earned by the artisans is sufficient for their children's education. The artisans experience a good working condition.

\section{Suggestions \& Recommendations}

- It is suggested that the government help in uplifting the kalamkari art.

- It is suggested that the artisans should be given opportunities to pursue education along with the art.

- It is suggested that the artisans should be aware of the banks to opt for loans.

\section{Bibliography}

https://en.wikipedia.org/wiki/Kalamkari. https://en.wikipedia.org/wiki/Pedana Kalamkari. Kalamkari Paintings, Indian Heritage, 2006.

Purohit, Pooja. The Study of Traditional Hand Painted Kalamkari to Design a set of New age Prints, Institutional Repository National Institute of Fasion Technology, 2015.

\section{Author Details}

G.Ramya Sri, Assistant Professor, Badruka College of Commerce and Arts, Hyderabad, Telangana, India. Email.ID: ramya12.in@gmail.com. 